Original Paper http://ajol.info/index.php/ijbcs http://indexmedicus.afro.who.int

\title{
Temporal variation in body measurements in three Taurine cattle populations of Burkina Faso supports introgression of Zebu genes into West African Taurine cattle
}

Arnaud Stéphane Rayangnéwêndé TAPSOBA ${ }^{1}$, Bernadette YOUGBARÉ ${ }^{1}$, Fabiola Gnine TRAORÉ ${ }^{1}$, Félicienne BÉRÉ ${ }^{2}$, Dominique OUÉDRAOGO ${ }^{3}$, Bienvenue Lassina ZOMA ${ }^{4}$, Moumouni SANOU ${ }^{1}$, Albert SOUDRÉ 5 , Vincent DAO ${ }^{6}$, Hamidou Hamadou TAMBOURA $^{1}$, Balé BAYALA ${ }^{7}$, Amadou TRAORÉ ${ }^{1 *}$ and Félix GOYACHE ${ }^{8}$

${ }^{1}$ Laboratoire de Biologie et Santé animales (LaBioSA), Institut de l'Environnement et de Recherches Agricoles (INERA), 04 BP 8645 Ouagadougou 04, Burkina Faso.

${ }^{2}$ Ministère des Ressources Animales et Halieutiques (MRAH), 01 BP : 7026 Ouagadougou 01, Burkina Faso. ${ }^{3}$ Université de Dédougou, BP 176 Dédougou, Burkina Faso.

${ }^{4}$ University of Natural Resources and Life Sciences, Division of Livestock Sciences, Department of Sustainable Agricultural Systems, Gregor Mendel Str. 33, 1180 Vienna, Austria.

${ }^{5}$ UFR Sciences et Techniques, Université Norbert Zongo de Koudougou (Burkina Faso), BP 376 Koudougou, Burkina Faso.

${ }^{6}$ INERA, Direction régionale de l'Ouest, Farakoba, Bobo-Dioulasso, BP 910 Bobo-Dioulasso.

${ }^{7}$ Université Joseph Ki-Zerbo, Unité de Formation et de Recherches en sciences de la vie et de la terre, 03 BP 7021 Ouagadougou 03 Burkina Faso.

${ }^{8}$ SERIDA-Deva, Camino de Rioseco 1225, E-33394 Deva-Gijón, Asturias, Spain.

*Corresponding author; E-mail: traore_pa@yahoo.fr; Tel: (+226)70429440

\section{ACKNOWLEDGEMENTS}

The authors are indebted to breeders involved in this study for their kind collaboration. This study made use of part of data generated under the CORAF/WECARD-World Bank no. 03/GRN/16 (Project Introgression).

\section{ABSTRACT}

A total of 769 adult females belonging to 3 taurine and one zebu cattle populations sampled in 3 provinces of Burkina Faso were assessed for 19 body measurements during two different years (2014 and 2018). The aim of this research was to identify temporal morphological variation in cattle bred in the humid southern zones to obtain empirical evidence supporting a possible introgression of zebu cattle genes into Gourounsi and Lobi taurine cattle breeds. Zebu cattle samples were used as out-group for both 2014 and 2018 subsets. Least square means of body measurements allowed to classify Burkina Faso taurine cattle into three subgroups according to body size (Gourounsi-Sanguié -GourS-, Gourounsi-Nahouri -GourN- and Lobi from the tallest to the smallest respectively). Principal Component Analysis suggested that in 2014, taurine populations were structured. Dispersion map constructed using the two first factors informed that the GourS population was well separated from both the Lobi and the GourN, which, in turn, overlapped. However, in 2018 a strong signal of homogenization was identified, with GourN partially overlapping the other two populations. Linear Discriminant Analysis suggested that about 20\% of both GourS and GourN individuals were reciprocally misclassified. Clues for such increase have been pointed out by MANOVA analysis. Although on 2014, Lobi cattle was clearly smaller than Gourounsi and both GourS and GourN 
populations showed clear differences on body traits, on 2018 it could be assessed an increase in size in Lobi cattle and a strong homogenization signal within Gourounsi cattle. Zebu cattle gene flow southwards in Burkina Faso is likely to have caused these changes, suggesting a fast erosion of taurine cattle genetic background.

(C) 2020 International Formulae Group. All rights reserved.

Keywords: Body traits, quantitative traits, Gourounsi cattle, Lobi, Burkina Faso.

\section{INTRODUCTION}

Taurine cattle (Bos Taurus) are believed to be the native original African cattle. Archeozoological and genetic evidences suggest that African humpless cattle were domesticated in the Fertile Crescent 8800 BC during the Neolithic (AjmoneMarsan et al., 2010; MacHugh et al., 2017). However, the occurrence of a separate domestication event in African B. taurus, divides scholars (Pitt et al., 2018; PérezPardal et al., 2010) and is still disputed. Supposed to had taken place during the $6^{\text {th }}$ millennium BC in Egypt valley (Blench et al., 2000; Wendorf and Schild, 2005), a putative African taurine cattle domestication is identified as the major historical event that enables the introduction of Shorthorn cattle in West Africa (MacDonald and Hutton MacDonald, 2000; Marshall and Hildebrand, 2002). It is hypothesized that increasing aridity in the Sahara may have forced the Shorthorn cattle migration westwards along the North African Mediterranean coast. Thus, they have been introduced in Sub-Saharan West Africa by the Berbers from southern Morocco (Henn et al., 2012). Their dissemination through tsetse challenged West African forests where caused they became trypanotolerant (MacDonald and Hutton MacDonald, 2000; Marshall and Hildebrand, 2002). Whatever the route might have been, Shorthorn cattle eventually evolved to create the present-day West African Shorthorn taurine populations. Furthermore, between 2000 and 3000 years BP, different migration waves of $B$. indicus cattle deeply changed the genetic landscape of African cattle (Hanotte et al., 2002; Pérez-Pardal et al., 2010). Shaped through long migrations and well adapted to dry environment and poor food (Mwai et al., 2015), Zebu cattle started and still ongoing process of absorption of humpless taurine cattle populations in West Africa. At present, African taurine cattle are mainly spread in the humid and sub-humid West and Central Africa where zebu cattle cannot perform due to trypanosomosis. Nowadays, introgression of zebu cattle into West African taurine cattle populations is strengthened by several factors causing that some taurine populations be on the brink of extinction. Global warming and human activities have reduced the rain forest area, therefore allowing penetration of zebu in taurine territories. Several authors (Traoré et al., 2009, 2012; Álvarez et al., 2009, 2014), using molecular markers have shown evidence of introgression of Sahelian livestock genes in sheep, goat and cattle. This work was undertaken to use multivariate assessment of morphological traits sampled in different periods (2014 and 2018) to give evidence supporting introgression of zebu cattle genes southwards in West African taurine cattle populations.

\section{MATERIALS AND METHODS}

Following the methodology described by Traoré et al. (2015), nineteen body measurements were obtained from 676 Burkina Faso B. taurus and B. indicus individuals belonging to 4 different populations. Individuals were representatives of the two taurine cattle breeds encountered in Burkina Faso: the Gourounsi and the Lobi breeds. The Gourounsi catlle are mainly spread in the central region of the country and were sampled in the Sanguié (GourS) and Nahouri (GourN) provinces. The Lobi cattle are mainly spread in the western region of the country and were sampled in the Ioba province. Zebu data were obtained from Zebu Peul individuals in the provinces of Oudalan and Soum belonging to the Northern Sahel region of the country (Figure 1). 


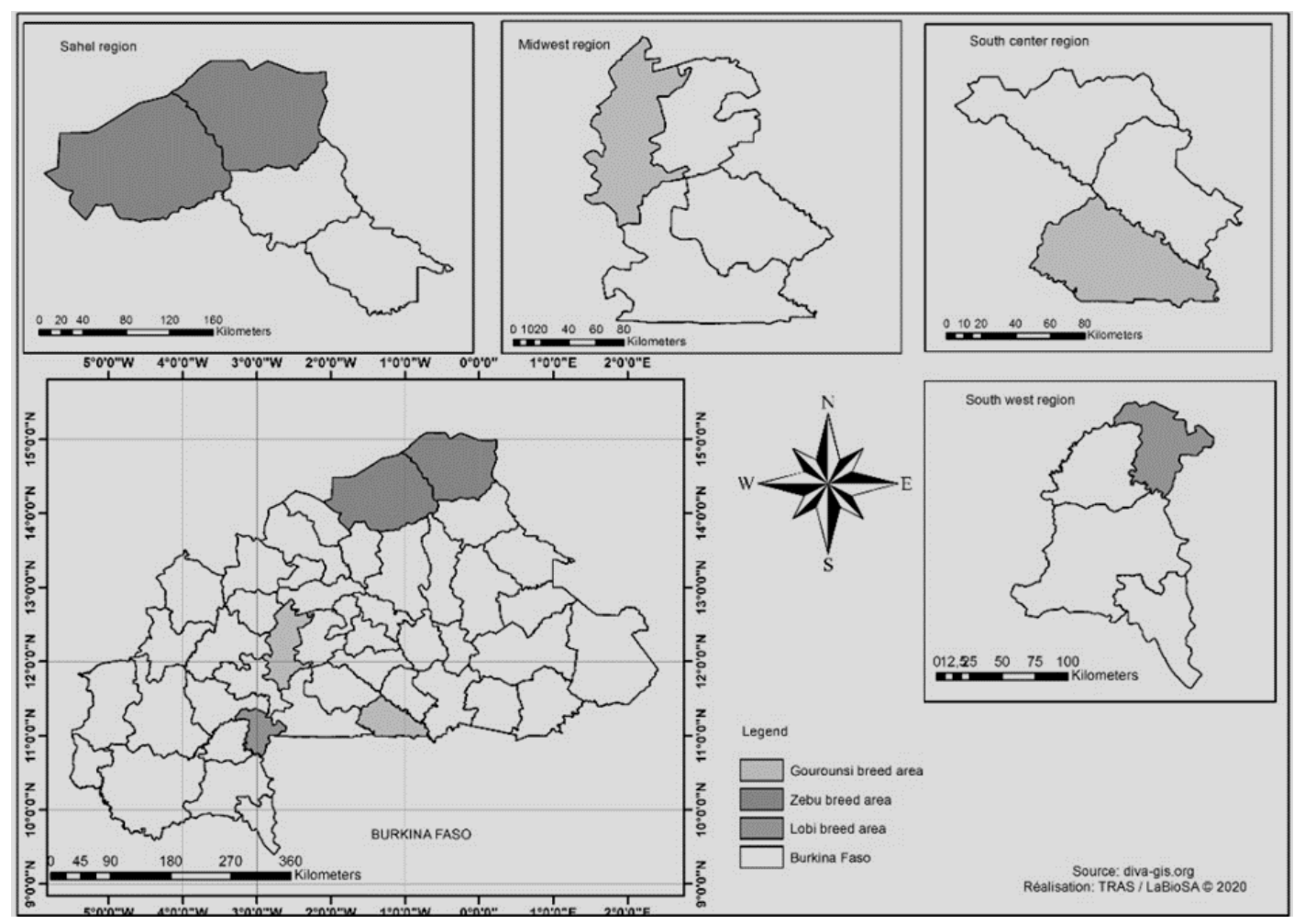

Figure 1: Sampling sites.

Nineteen quantitative traits were assessed according to the FAO/ISAG (FAO, 2011) guidelines for cattle characterization. Animal age was approached by dentition and ranged between 3 and 13 years old. Body measurements were carried out, with the animals standing stationary on a flat floor, using a Lydthin stick, a tape measure, and a Vernier caliper. Recorded body measurements were the following: Head length (from bun to middle of muffle); Head width (distance between the depression located below each horn); Cranial width (minimum width of the frontal bone); Cranial length (from the bun to the middle of the head); Facial length (from orbital fossa to upper lip); Muzzle circumference; Ear length; Horn length (greater curvature); Ischial scapular length (from lateral tuberosity of the humerus to tuber ischia); Chest depth (distance from the brisket between the front legs to withers) ; Heart girth; Chest width (the distance between the axis of the forelimbs at the base of the sternum); Pelvis length ; Height at the sacrum (the vertical distance between the ground and the point determined by the intersection between the line passing through the points of the hips and the sacrum); Height at withers (height from the withers to the ground); Hips width (measured between the two wings of the ilium) ; Ischium width (between tuber ischii) and Tail length.

The statistical analyses were carried out using $\mathrm{R}$ (http://www.R-project.org/). Morphological data were collected on years 2014 and 2018. The two subsets of data (2014 and 2018) were compared with the same set of body measurements obtained in sample Zebu Peul which was used as out-group. Principal Component Analysis (PCA) was performed 
using the package factoextra (Kassambara, 2015). Then an ascendant hierarchical classification was carried out. Prior to clustering, the optimal number of clusters was assessed using the Package Nbclust (Charrad et al., 2014). The degree of admixture between breeds in 2014 and 2018, was assessed using linear discriminant analysis (LDA) which estimates the proportion of animals that were properly classified into their original breed. The GLM package was used to assess the effect of the breed on all body measurements. The linear model fitted included the breed and the year as fixed effects and the interaction between the breed and year of data collection. Least-square means and their corresponding standard errors were obtained using the package emmeans (Lenth, 2019). To ascertain the influence of time on the variation of morphological measurements, all data (2014 and 2018) were merged, zebu measurements removed and Multivariate analysis of Variance (MANOVA) was carried out. The model included all recorded traits as dependent variables (model $=\mathrm{X} \sim \mathrm{Y}$ with $\mathrm{X}$ being all regrouped morphological variables and $\mathrm{Y}=$ Year of samples collection). Moreover, variables that have significantly changed between 2014 and 2018 were identified through MANOVA in a model including the breed as independent variable.

\section{RESULTS}

Relationships between traits were
analyzed constructing bidimensional
dispersion plots (Figures 1 and 2). The two
first components of the 2014's PCA plot
accounted for $66.6 \%$ of the total variability
while in the 2018 subset the two first
components explained $69 \%$ of the total
variability of data (Table 1). Strong
similitudes were found between these plots
(PCA 2014 and PCA 2018). From 2014 to
2018, eleven traits gather most morphological

variability in the studied populations (Head length, Height at sacrum Height at withers, Head width, Horn length, Thorax depth, Chest perimeter, Cranial width, Cranial length, Ischial scapular length and Chest width). These variables were positively and strongly correlated $(>0.6)$ to the first PC that accounted for 49.2 and $61.6 \%$ of the total variance in 2014 and 2018, respectively (Table 1). Besides, some variables of the first dimension showed different evolutionary pattern from 2014 to 2018. The Facial, Pelvis and Ear length, Muzzle circumference, Hip width and Ischial wide had a medium to low correlation with the first component in 2014 while in 2018 this correlation was strong. The Tail length was negatively correlated with the first PC in both periods of sampling. The second component had strong and positive correlations with Ischium width and Hips width, respectively, both in 2014 and 2018 . Moreover, 2014's PC2 had many negative correlations, which were higher, in absolute values, than those seen in the second component of the 2018's PCA plot.

The bidimensional map constructed with the individuals sampled in 2014, displayed 4 different clusters belonging to each of the four populations samples (Figure 3). Gourounsi from Nahouri (GourN) and Lobi populations clustered together while Zebu Peul and Gourrounsi from Sanguie (GourS) clusters were well separated. Regarding the individual's characteristics, the first component of the PCA plot separated individuals characterized by high morphometrics values (on the right of the Xaxis) to individuals characterized by weak phenotypic attributes (on the left of the Xaxis).

The first group was mainly composed by Zebu Peul and included individuals with high morphological values for Cranial length, Head width, Cranial width, Head length, Height at the sacrum, Height at 
withers, Horn length, Ear length, Chest perimeter and Ischial scapular length. Moreover, variables like Tail length and Ischium width are not well developed in this breed. The second group, (characterized by a negative coordinate on the axis) shared low values for Pelvis length, Facial length, Ischial scapular length, Height at the sacrum, Height at withers, Thorax depth, Head length, Horn length, Chest perimeter and Ischium width. On the PCA plot, overlapping clusters of Taurine lobi and GourN populations represents this group. The third group was mainly composed by GourN individuals and was characterized by high values for the variables Tail length, Ischium width, Pelvis length, Facial length and Hips width and low values for Ear length, Cranial length, Cranial width, Head width, Head length, Chest width, Height at the sacrum, Horn length, Heigth at withers and Chest perimeter.

Similarly, to the 2014's individuals factor map, the 2018's individuals PCA plot displays 4 different clusters belonging to each of the four breeds of the study (Figure 4). In 2018, the three taurine breeds clustered together while zebu's peul is well separated. The first dimension opposes well-shaped individuals to individuals characterized by lower morphological measurements. Group 1 (characterized by a positive coordinate on the axis) shared high values for Head length, Chest width, Facial length, Height at the sacrum, Cranial length, Cranial width, Height at withers, Horn length, Pelvis length and Ischial scapular length and low values Tail length. The group 2 (characterized by a positive coordinate on the $\mathrm{X}$-axis) shared: high values for Chest perimeter, Thorax depth, Muzzle circumference, Head width, Height at the sacrum, Head length, Height at withers, Hips width, Ear length and Facial length and low values for Tail length.

Group 3 (characterized by a negative coordinate on the $\mathrm{X}$ axis): high values for Tail length and low values for Head length, Height at the sacrum, Facial length, Height at withers, Head width, Cranial width, Cranial length, Ischial scapular length, Pelvis length and Horn length. Head length, Lobi and Zebu-peul are highly correlated with this component (respective correlation of $0.93,0.94,0.98$ ) and could therefore summarize themselves the component 1 .

To accurately describe the variability in the two data subsets, a hierarchical ascendant classification has been performed. Moreover, to optimize the description of the variability, the optimal number of clusters has been determined based on the method proposed by Kassambara et al. (2008). In 2014 , the optimal number of clusters was $\mathrm{k}=3$ and $\mathrm{k}=4$ in 2018. The hierarchical classification allowed to identify 3 groups (Figure 5) in the 2014 subset.

The first cluster was mainly composed by Lobi $(89.15 \%)$ and GourN (94.80\%) individuals with a low proportion of GourS (7.25\%) individuals. The second cluster was almost exclusively composed by GourS (91.30\%) individuals. All Zebu Peul individuals were included in the third cluster $(89.79 \%)$. Few individuals from GourN $(6.80 \%)$ and Lobi $(2.04 \%)$ were also found in this group (Table 2).

The 2018's hierarchical classification revealed the existence of 4 different groups (Figure 6).

The first group mainly included Lobi cattle $(92.45 \%)$. The second group had a balanced composition of Taurine GourN and GourS (60\% vs $62.96 \%)$. The third and fourth groups were mainly composed of Zebu Peul with few individuals belonging to both Gourounsi (GourN and GourS) populations (Table 3).

The predicted classes are shown in Table 4 . GourN counts $2.31 \%$ of misclassified individuals (1.54 as GourS and $0.77 \%$ as Lobi). Up to $98.7 \%$ of Lobi individuals were 
correctly classified. This population seems to share morphological identity with GourN individuals where $1.3 \%$ of misclassified Lobi individual are found. However, no morphological similitude was found between Lobi and GourS. Consistently with the PCA plot, $100 \%$ of the GourS individuals were correctly classified.

In 2018, the proportion of individual sharing similitudes between GourS and GourN was about $20 \%$ in each group (found as misclassified). As describe in 2014, none of GourS individual has been misclassified as Lobi breed. But $7.27 \%$ of Lobi individuals have been reported by the LDA as GourS and $5.45 \%$ as GourN (Table 5).

Least square means estimated for each body measurement are given in Table 6 per breed and year. The effect of the interaction between breed and time has been tested to assess morphological trends. No between-years mean values in the GourN population were statistically different for alpha $=0.05$. However, except for Head length, Thorax perimeter, the Chest width and Muzzle circumference, all body measurement increased in GourS breed between 2014 and 2018. Consistently, in Lobi breed, parameters such as Face length, Horn length, Height at gird, Thorax depth, Ischial scapular length, Pelvis length, Chest width, Hips width and Ear length significantly increased between 2014 and 2018. Based on the Height at withers, Burkina Faso taurine could be classified in three groups: small (Lobi), medium (GourN) and big (GourS).

Across the years, a clear increase in morphological traits was ascertained by the Multivariate Analysis of Variance results. Except for head width, cranial width, horn length, thorax depth, and chest perimeter, all recorded traits measurements from 2014 to 2018 showed a significant increase (Table 7).

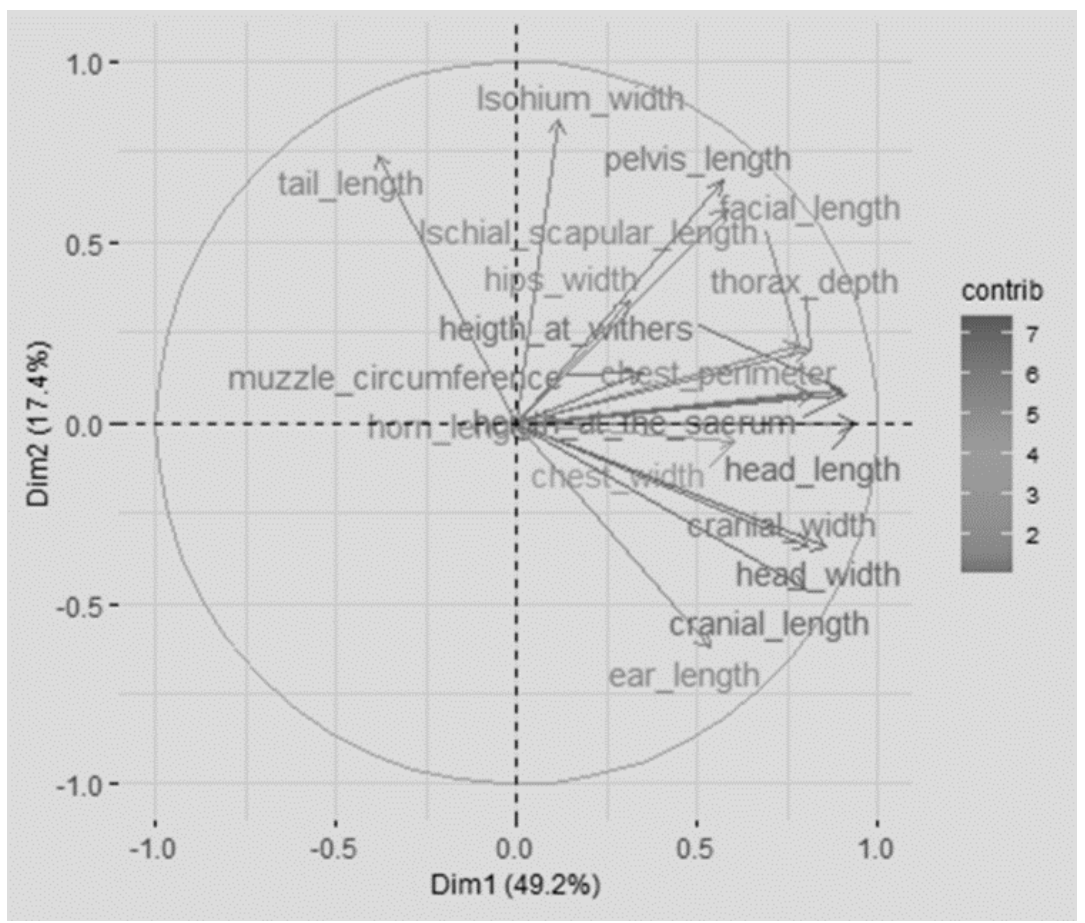

Figure 2: Correlations between Variables to PC1 and PC2 plot (year 2014). 
A. S. R. TAPSOBA et al. / Int. J. Biol. Chem. Sci. 14(8): 2782-2798, 2020

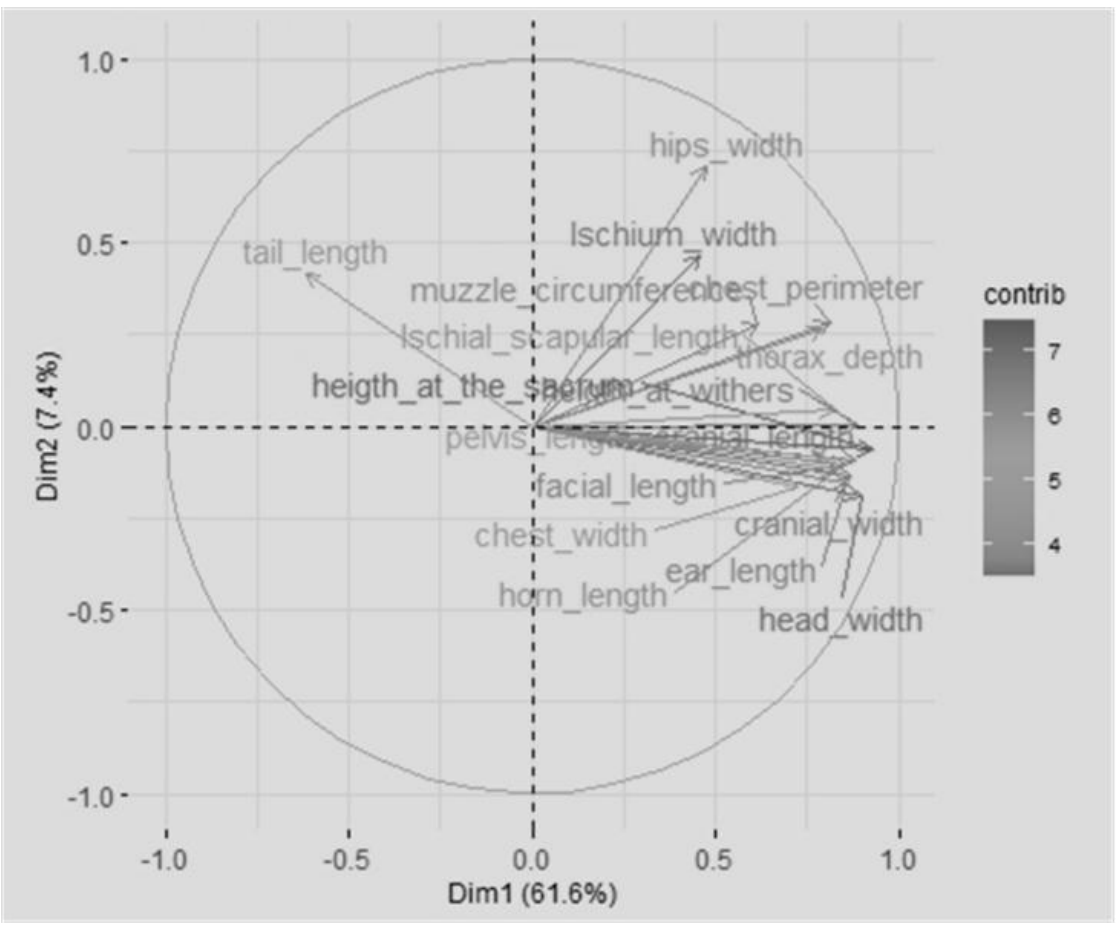

Figure 3: Correlations between traits and factors to PC1 and PC2 (year 2018).

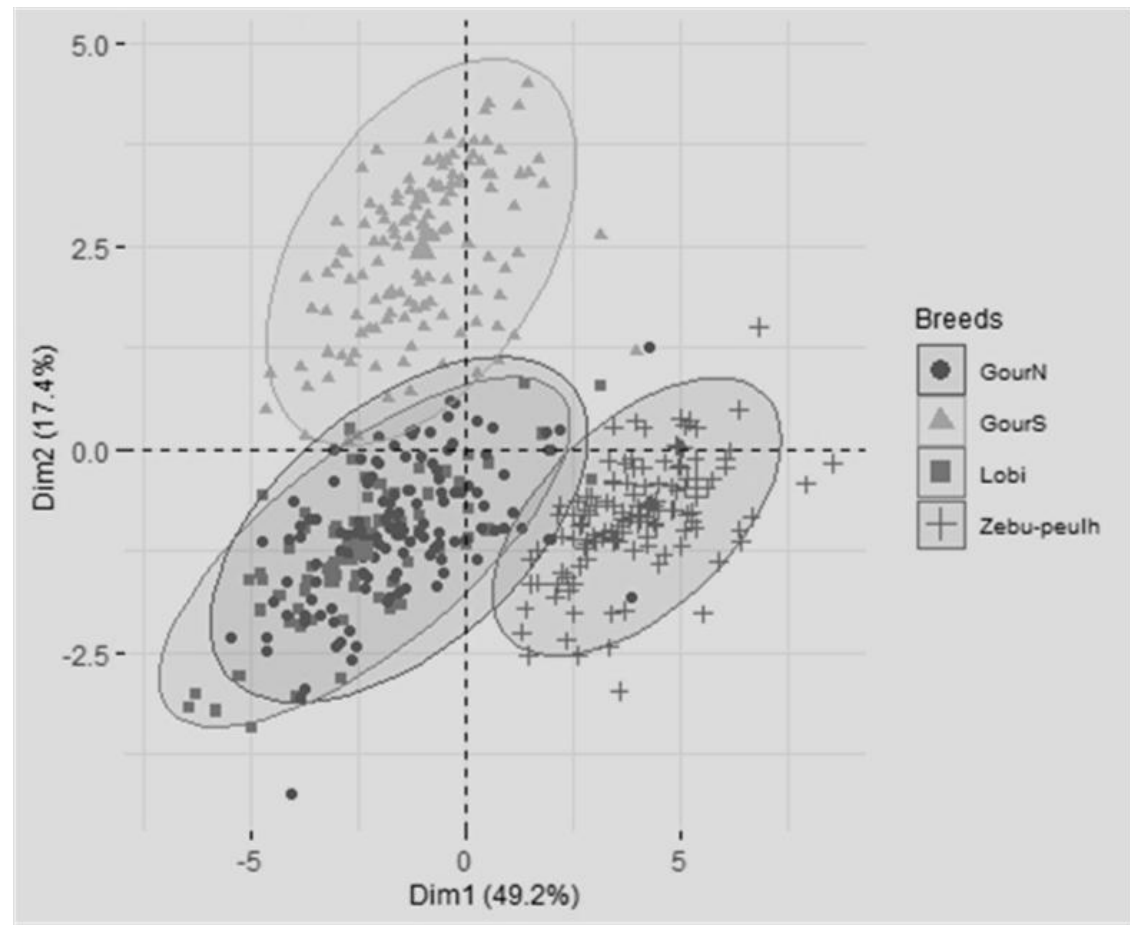

Figure 4: Bidimensional plot showing dispersion of the individuals sampled in 2014. 
A. S. R. TAPSOBA et al. / Int. J. Biol. Chem. Sci. 14(8): 2782-2798, 2020

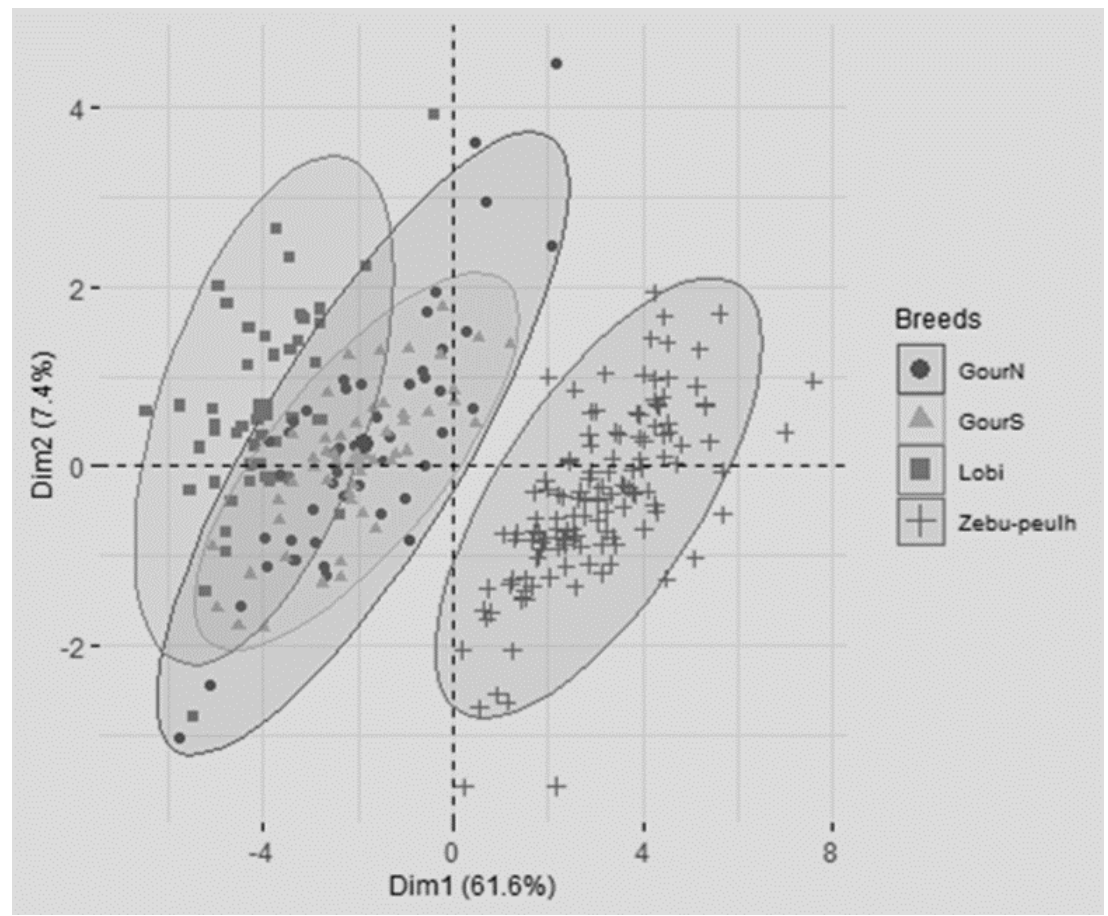

Figure 5: Individual factor map 2018.

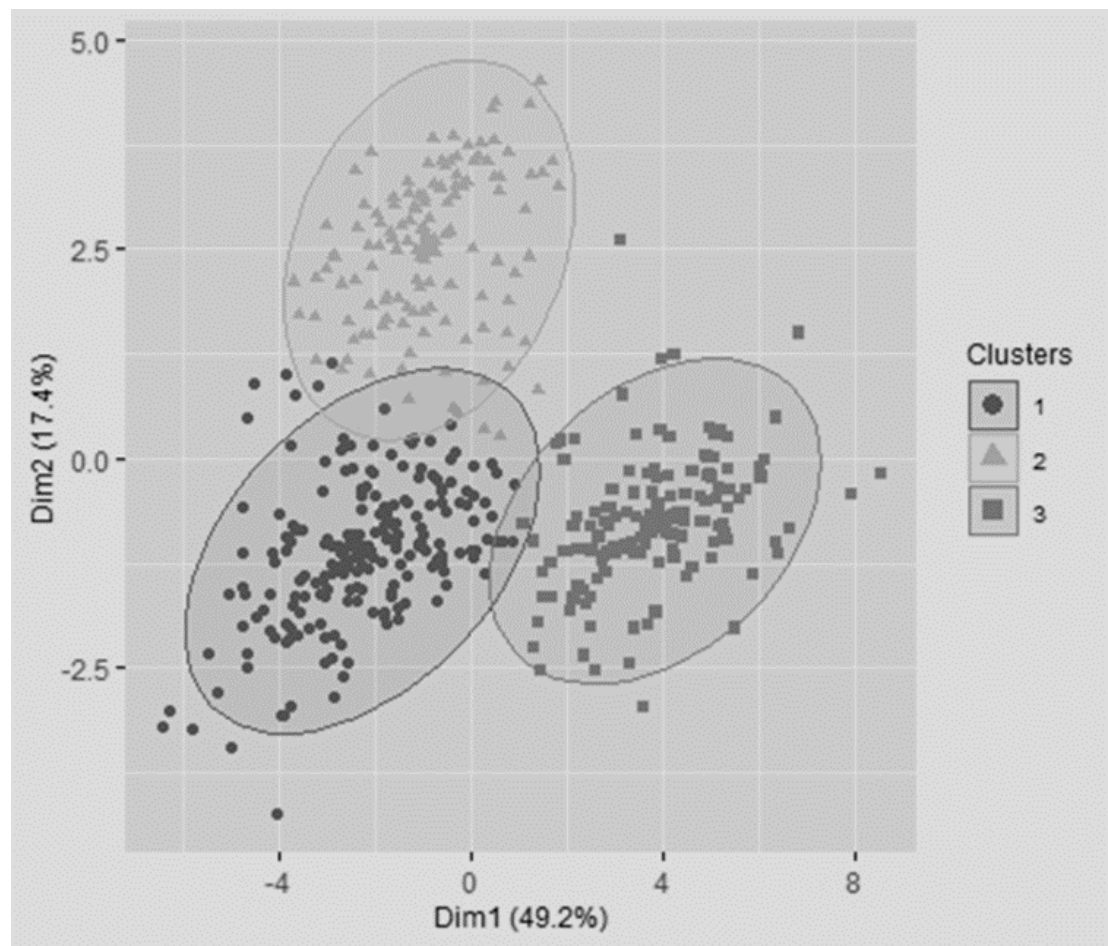

Figure 6: Hierarchical classification plot corresponding to the 2014 subset. 


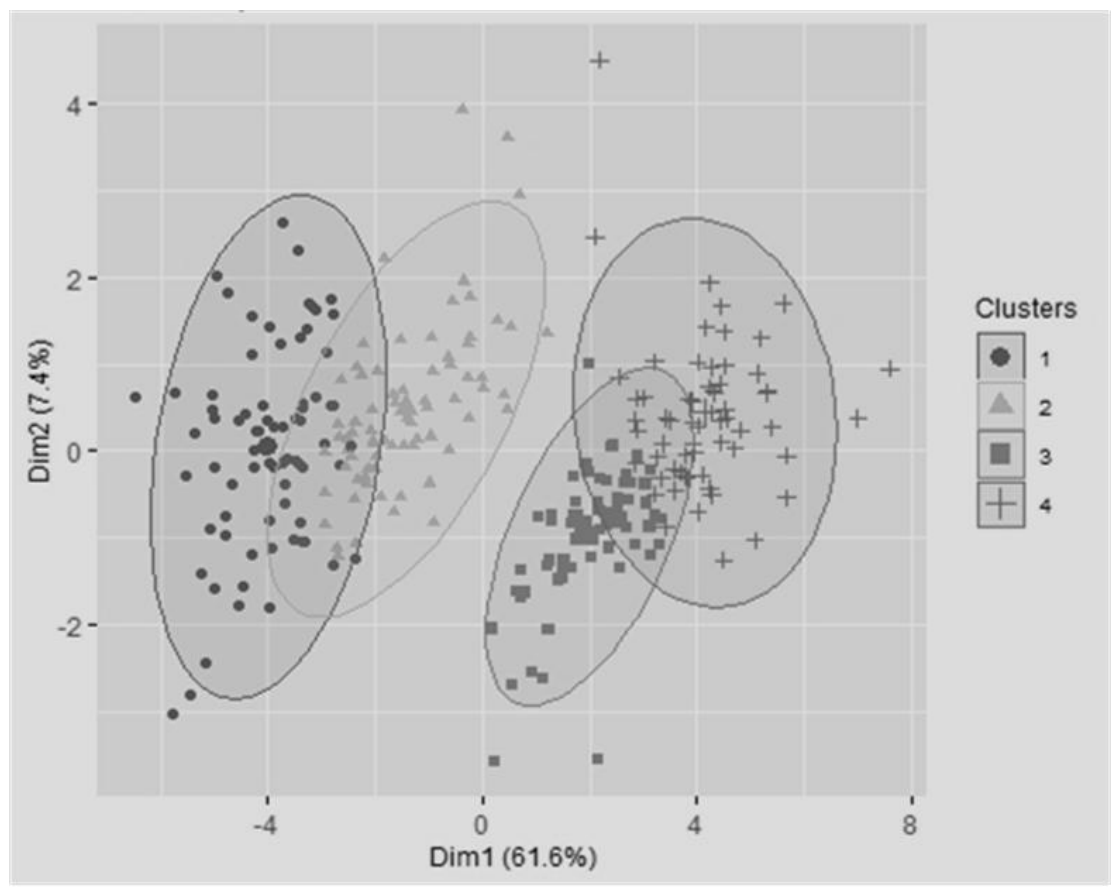

Figure 7: Hierarchical classification plot corresponding to the 2018 subset.

Table 1: Variables correlation table in 2014 and 2018 PCA's plots.

\begin{tabular}{lllll}
\hline Parameters & PC 1 & PC 2 & PC1 & PC2 \\
\hline Proportion of variation & 49.2 & 17.4 & 61.6 & 7.4 \\
Head length & 0.93 & - & 0.96 & -0.12 \\
Height at the sacrum & 0.91 & - & 0.93 & - \\
Height at withers & 0.9 & 0.09 & 0.89 & - \\
Head width & 0.86 & -0.35 & 0.9 & -0.19 \\
Horn length & 0.82 & - & 0.83 & -0.12 \\
Thorax depth & 0.81 & 0.2 & 0.79 & 0.26 \\
Chest perimeter & 0.81 & - & 0.81 & 0.28 \\
Cranial width & 0.81 & -0.34 & 0.87 & -0.13 \\
Cranial length & 0.8 & -0.46 & 0.88 & - \\
Ischial scapular length & 0.78 & 0.21 & 0.82 & - \\
Chest width & 0.61 & - & 0.73 & -0.16 \\
Facial length & 0.58 & 0.59 & 0.86 & - \\
Pelvis length & 0.57 & 0.67 & 0.8 & - \\
Ear length & 0.54 & -0.62 & 0.86 & -0.16 \\
Muzzle circumference & 0.35 & 0.14 & 0.62 & 0.28 \\
Hips width & 0.31 & 0.34 & 0.47 & 0.71 \\
Ischium width & 0.12 & 0.84 & 0.46 & 0.46 \\
Tail length & -0.38 & 0.74 & -0.62 & 0.41 \\
\hline \multicolumn{1}{c}{ PC: Principal component. } & & &
\end{tabular}


Table 2: Composition of the hierarchical classification Clusters (2014).

\begin{tabular}{lllllll}
\hline & \multicolumn{2}{c}{ Cluster 1 } & \multicolumn{2}{c}{ Cluster 2 } & \multicolumn{2}{c}{ Cluster 3 } \\
\hline Breeds & Cla/Mod & Mod/Cla & Cla/Mod & Mod/Cla & Cla/Mod & Mod/Cla \\
GourN & 89.15 & 58.08 & 3.10 & 3.05 & 7.75 & 6.80 \\
Lobi & 94.80 & 36.87 & 1.30 & 0.76 & 3.90 & 2.04 \\
GourS & 7.25 & 5.05 & 91.30 & 96.18 & 1.45 & 1.36 \\
Zebu-peul & 0 & 0 & 0 & 0 & 100 & 89.79 \\
\hline
\end{tabular}

Cla/Mod: Class / modality.

Table 3: Composition of the hierarchical classification Clusters (2018).

\begin{tabular}{lcccccccc}
\hline \multirow{2}{*}{ Breeds } & \multicolumn{2}{c}{ Cluster1 } & \multicolumn{2}{c}{ Cluster 2 } & \multicolumn{2}{c}{ Cluster 3 } & \multicolumn{2}{c}{ Cluster 4 } \\
\cline { 2 - 8 } & Clas/mod & Mod/clas & Clas/mod & Mod/clas & Clas/mod & Mod/clas & Clas/mod & Mod/clas \\
\hline GourN & 0 & 0 & 60.00 & 44.11 & 0 & 0 & 4.00 & 2.40 \\
GourS & 0 & 0 & 62.96 & 50.00 & 1.85 & 1.40 & 0 & 0 \\
Lobi & 92.45 & 56.32 & 7.54 & 5.88 & 0 & 0 & 0 & 0 \\
Zébu Peulh & 0.65 & 1.14 & 0 & 0 & 46.05 & 98.59 & 53.28 & 97.59 \\
\hline
\end{tabular}

Table 4: Linear discriminant analysis predictions 2014.

\begin{tabular}{lcccc}
\hline Predicted classes & GourN & GourS & Lobi & Zebu-peul \\
\hline GourN & 97,69 & 1,54 & 0,77 & 0 \\
GourS & 0 & 100 & 0 & 0 \\
Lobi & 1,3 & 0 & 98,7 & 0 \\
Zebu-peul & 0,75 & 0 & 0 & 99,25 \\
\hline
\end{tabular}

GourN: Gourounsi of Nahouri ; GourS: Gourounsi of Sanguié.

Table 5: Linear discriminant analysis predictions for the 2018 subset.

\begin{tabular}{lllll}
\hline Predicted classes & GourN & GourS & Lobi & Zebu-peul \\
\hline GourN & 75,56 & 20 & 4,44 & 0 \\
GourS & 21,15 & 78,85 & 0 & 0 \\
Lobi & 7,27 & 5,45 & 87,27 & 0 \\
Zebu-peulh & 0 & 0 & 0 & 100 \\
\hline
\end{tabular}

GourN: Gourounsi of Nahouri ; GourS: Gourounsi of Sanguié. 
Table 6: Least square means and standard deviation of body measurements from 2014 to 2018 .

\begin{tabular}{|c|c|c|c|c|c|c|}
\hline \multirow[b]{2}{*}{ parameters } & \multicolumn{2}{|c|}{ GourN } & \multicolumn{2}{|c|}{ GourS } & \multicolumn{2}{|c|}{ Lobi } \\
\hline & {$[2014]$} & [2018] & [2014] & [2018] & [2014] & [2018] \\
\hline Head length & $43,41 \pm 0,17^{\mathrm{a}}$ & $42,39 \pm 0,23^{\mathrm{a}}$ & $43,71 \pm 0,17^{\mathrm{a}}$ & $42,69 \pm 0,23^{\mathrm{a}}$ & $40,33 \pm 0,22^{\mathrm{a}}$ & $39,31 \pm 0,24^{\mathrm{a}}$ \\
\hline Head width & $19,38 \pm 0,14^{\mathrm{a}}$ & $19,46 \pm 0,18^{a}$ & $17,79 \pm 0,14^{\mathrm{a}}$ & $17,87 \pm 0,18^{\mathrm{b}}$ & $17,8 \pm 0,17^{\mathrm{a}}$ & $17,88 \pm 0,1^{\mathrm{a}}$ \\
\hline Cranial length & $21,07 \pm 0,12^{\mathrm{a}}$ & $22,03 \pm 0,17^{\mathrm{a}}$ & $19,55 \pm 0,13^{\mathrm{a}}$ & $20,51 \pm 0,16^{\mathrm{b}}$ & $19,96 \pm 0,16^{\mathrm{a}}$ & $20,91 \pm 0,17^{\mathrm{a}}$ \\
\hline Cranial width & $16,38 \pm 0,13^{\mathrm{a}}$ & $16,49 \pm 0,17^{\mathrm{a}}$ & $15,14 \pm 0,13^{\mathrm{a}}$ & $15,24 \pm 0,17^{b}$ & $15,2 \pm 0,16^{\mathrm{a}}$ & $15,31 \pm 0,18^{a}$ \\
\hline Facial length & $22,34 \pm 0,15^{\mathrm{a}}$ & $20,03 \pm 0,2^{\mathrm{a}}$ & $24,83 \pm 0,15^{\mathrm{a}}$ & $22,52 \pm 0,2^{\mathrm{b}}$ & $20,5 \pm 0,19^{a}$ & $18,19 \pm 0,21^{\mathrm{b}}$ \\
\hline Horn length & $17,49 \pm 0,5^{\mathrm{a}}$ & $18,55 \pm 0,66^{\mathrm{a}}$ & $21,37 \pm 0,5^{\mathrm{a}}$ & $22,43 \pm 0,65^{b}$ & $14,06 \pm 0,62^{\mathrm{a}}$ & $15,11 \pm 0,68^{\mathrm{b}}$ \\
\hline Height at withers & $95,69 \pm 0,43^{\mathrm{a}}$ & $100,94 \pm 0,58^{a}$ & $97,46 \pm 0,44^{\mathrm{a}}$ & $102,72 \pm 0,57^{b}$ & $88,18 \pm 0,55^{\mathrm{a}}$ & $93,43 \pm 0,6^{\mathrm{a}}$ \\
\hline Thorax depth & $49,75 \pm 0,24^{\mathrm{a}}$ & $50,25 \pm 0,33^{\mathrm{a}}$ & $50,96 \pm 0,24^{\mathrm{a}}$ & $51,46 \pm 0,32^{\mathrm{b}}$ & $49,33 \pm 0,31^{\mathrm{a}}$ & $49,83 \pm 0,34^{\mathrm{b}}$ \\
\hline $\begin{array}{l}\text { Height at the } \\
\text { sacrum }\end{array}$ & $99,2 \pm 0,45^{\mathrm{a}}$ & $104,5 \pm 0,59^{a}$ & $101,97 \pm 0,45^{a}$ & $107,27 \pm 0,59^{b}$ & $91 \pm 0,56^{\mathrm{a}}$ & $96,3 \pm 0,61^{\mathrm{a}}$ \\
\hline $\begin{array}{l}\text { Ischial scapular } \\
\text { length }\end{array}$ & $103,6 \pm 0,69^{a}$ & $111,01 \pm 0,93^{\mathrm{a}}$ & $115,62 \pm 0,7^{\mathrm{a}}$ & $123,03 \pm 0,91^{\mathrm{b}}$ & $109,45 \pm 0,87^{\mathrm{a}}$ & $116,86 \pm 0,96^{\mathrm{b}}$ \\
\hline Pelvis length & $34,51 \pm 0,29^{\mathrm{a}}$ & $31,83 \pm 0,38^{\mathrm{a}}$ & $40,26 \pm 0,29^{a}$ & $37,58 \pm 0,38^{\mathrm{b}}$ & $33,15 \pm 0,36^{a}$ & $30,47 \pm 0,39^{\mathrm{b}}$ \\
\hline Ischium width & $11,92 \pm 0,16^{\mathrm{a}}$ & $10,54 \pm 0,21^{\mathrm{a}}$ & $15,15 \pm 0,16^{\mathrm{a}}$ & $13,77 \pm 0,21^{\mathrm{b}}$ & $12,41 \pm 0,2^{\mathrm{a}}$ & $11,04 \pm 0,22^{\mathrm{a}}$ \\
\hline Tail length & $98,63 \pm 0,86^{\mathrm{a}}$ & $95,9 \pm 1,15^{\mathrm{a}}$ & $108,87 \pm 0,86^{a}$ & $106,14 \pm 1,14^{\mathrm{b}}$ & $88,38 \pm 1,08^{a}$ & $85,65 \pm 1,19^{a}$ \\
\hline Chest perimeter & $134,7 \pm 0,72^{\mathrm{a}}$ & $136,56 \pm 1,22^{\mathrm{a}}$ & $134,85 \pm 0,72^{\mathrm{a}}$ & $134,56 \pm 1,17^{\mathrm{a}}$ & $131,06 \pm 0,97^{\mathrm{a}}$ & $132,18 \pm 1,18^{\mathrm{a}}$ \\
\hline Chest width & $15,02 \pm 0,18^{\mathrm{a}}$ & $14,84 \pm 0,3^{\mathrm{a}}$ & $15,66 \pm 0,18^{\mathrm{a}}$ & $15,06 \pm 0,29^{\mathrm{a}}$ & $16,59 \pm 0,24^{\mathrm{a}}$ & $12,02 \pm 0,29^{\mathrm{b}}$ \\
\hline Hips width & $28,29 \pm 0,23^{\mathrm{a}}$ & $26,97 \pm 0,31^{\mathrm{a}}$ & $29,86 \pm 0,23^{\mathrm{a}}$ & $28,54 \pm 0,3^{\mathrm{b}}$ & $30,96 \pm 0,29^{a}$ & $29,64 \pm 0,32^{\mathrm{b}}$ \\
\hline $\begin{array}{l}\text { Muzzle } \\
\text { circumference }\end{array}$ & $37,29 \pm 0,2^{\mathrm{a}}$ & $35,46 \pm 0,27^{\mathrm{a}}$ & $36,82 \pm 0,2^{\mathrm{a}}$ & $34,99 \pm 0,27^{\mathrm{a}}$ & $36,22 \pm 0,26^{\mathrm{a}}$ & $34,4 \pm 0,28^{a}$ \\
\hline Ear length & $37,29 \pm 0,2^{\mathrm{a}}$ & $35,46 \pm 0,27^{\mathrm{a}}$ & $36,82 \pm 0,2^{\mathrm{a}}$ & $34,99 \pm 0,27^{b}$ & $36,22 \pm 0,26^{\mathrm{a}}$ & $34,4 \pm 0,28^{\mathrm{b}}$ \\
\hline
\end{tabular}

a,b,c Row means with different superscripts differ significantly at $\mathrm{P}<0.05$.

GourN: Gourounsi of Nahouri ; GourS: Gourounsi of Sanguié.

Table 7: Evolution of morphometric variables across the years (MANOVA results).

\begin{tabular}{|c|c|c|c|c|c|c|c|}
\hline Trait & model & Df & SumSq & MeanSq & F value & $\operatorname{Pr}(>\mathbf{F})$ & \\
\hline \multirow[t]{2}{*}{ Head length } & year & 1 & 219.3 & 219.25 & 30.79 & $4.558 \mathrm{e}-08$ & $* * *$ \\
\hline & Residuals & 522 & 3716.1 & 7.11 & & & \\
\hline \multirow[t]{2}{*}{ Head width } & year & 1 & 0.21 & 0.20 & 0.05 & 0.817 & \\
\hline & Residuals & 522 & 2014.24 & 3.85 & & & \\
\hline \multirow[t]{2}{*}{ Cranial length } & year & 1 & 86.9 & 86.89 & 27.536 & $2.247 \mathrm{e}-07$ & $* * *$ \\
\hline & Residuals & 522 & 1647.3 & 3.15 & & & \\
\hline \multirow[t]{2}{*}{ Cranial width } & year & 1 & 0.04 & 0.03 & 0.0112 & 0.9158 & \\
\hline & Residuals & 522 & 1664.45 & 3.18 & & & \\
\hline \multirow[t]{2}{*}{ Facial length } & year & 1 & 774.0 & 773.96 & 112.78 & $<2.2 \mathrm{e}-16$ & $* * *$ \\
\hline & Residuals & 522 & 3582.3 & 6.86 & & & \\
\hline \multirow[t]{2}{*}{ Horn length } & year & 1 & 23.4 & 23.37 & 0.457 & 0.499 & \\
\hline & Residuals & 522 & 26689.8 & 51.13 & & & \\
\hline Ischium width & year & 1 & 234.8 & 234.76 & 35.88 & $3.9 \mathrm{e}-09$ & $* * *$ \\
\hline
\end{tabular}




\begin{tabular}{|c|c|c|c|c|c|c|c|}
\hline & Residuals & 522 & 3415.0 & 6.542 & & & \\
\hline \multirow[t]{2}{*}{ Pelvis length } & year & 1 & 1065.1 & 1065.09 & 44.81 & $5.619 \mathrm{e}-11$ & $* * *$ \\
\hline & Residuals & 522 & 12407.6 & 23.77 & & & \\
\hline \multirow[t]{2}{*}{ Heigth at withers } & year & 1 & 1989.1 & 1989.11 & 42.79 & $1.453 \mathrm{e}-10$ & $* * *$ \\
\hline & Residuals & 522 & 24262.9 & 46.48 & & & \\
\hline \multirow[t]{2}{*}{ Ischial scapular length } & year & 1 & 6309 & 6308.6 & 56.96 & $1.987 \mathrm{e}-13$ & $* * *$ \\
\hline & Residuals & 522 & 57806 & 110.7 & & & \\
\hline \multirow[t]{2}{*}{ Heigth at the sacrum } & year & 1 & 1910 & 1910.00 & 36.04 & $3.606 \mathrm{e}-09$ & $* * *$ \\
\hline & Residuals & 522 & 27658 & 52.98 & & & \\
\hline \multirow[t]{2}{*}{ Thorax depth } & year & 1 & 17.4 & 17.44 & 1.619 & 0.20 & \\
\hline & Residuals & 522 & 5623.5 & 10.77 & & & \\
\hline \multirow[t]{2}{*}{ Tail length } & year & 1 & 2181 & 2180.62 & 11.30 & 0.00 & $* * *$ \\
\hline & Residuals & 522 & 100713 & 192.94 & & & \\
\hline \multirow[t]{2}{*}{ Chest perimeter } & year & 1 & 19 & 19.34 & 0.25 & 0.61 & \\
\hline & Residuals & 522 & 39757 & 76.162 & & & \\
\hline \multirow[t]{2}{*}{ Chest width } & year & 1 & 297.7 & 297.69 & 55.22 & $4.432 \mathrm{e}-13$ & $* * *$ \\
\hline & Residuals & 522 & 2814.1 & 5.39 & & & \\
\hline \multirow[t]{2}{*}{ Earl ength } & year & 1 & 149.52 & 149.52 & 33.71 & $1.108 \mathrm{e}-08$ & *** \\
\hline & Residuals & 522 & 2314.79 & 4.43 & & & \\
\hline \multirow[t]{2}{*}{ Muzzle circumference } & year & 1 & 411.9 & 411.90 & 55.75 & $3.462 \mathrm{e}-13$ & $* * *$ \\
\hline & Residuals & 522 & 3856.1 & 7.39 & & & \\
\hline \multirow[t]{2}{*}{ Hips width } & year & 1 & 125.0 & 125.02 & 12.20 & 0.00 & $* * *$ \\
\hline & Residuals & 522 & 5345.4 & 10.24 & & & \\
\hline
\end{tabular}

\section{DISCUSSION}

Morphological measurements are a useful tool to describe variability within and between populations. Therefore, it has been used in the characterization of several animals' populations worldwide (Ndumu et al., 2008; Youssao et al., 2010, Fagnon et al., 2013, Khan et al., 2013; Boujenane and Petit, 2016; Traoré et al., 2016, Yahaya et al., 2019). Based on morphometric measurements, Burkina Faso taurine cattle populations may be classified into three subgroups according to body size. From the tallest to the smallest we have GourS, GourN and Lobi. Similar findings have been reported by Traore et al. (2016). This observation is consistent with previous works on West African shorthorn cattle (Traore et al., 2016). Within and between breeds morphometric measurements increased from 2014 to 2018. Such evolution affected the distribution of the variability. PCA suggested that in 2014, Burkina Faso taurine cattle had a structure related with body traits. The GourS population was well separated from both the Lobi and the GourN populations, which, in turn, overlapped in the dispersion plot, constructed using PCA. This observation was confirmed with the hierarchical classification allowing the identification of two distinct clusters. Regarding the 2014 subset, this characterizes GourS as a differentiated population at the body traits level. However, regarding the 2018 subset, the increase of mean values for body traits in GourN and Lobi populations, is reflected in Figure 5 with overlapping 
clusters. This could be interpreted as a weak structure of the taurine populations in this subset. However, the hierarchical classification revealed that; a) Lobi individuals forming a homogeneous cluster; and b) the GourS and GourN individuals' groups. When compared to the 2014 results, the PCA and the hierarchical classification carried out on the 2018 subset suggested that a homogenization of Burkina GoursN and GourS population occurred. The most likely explanation of this change is an important gene flow between these two populations. However, an alternative explanation could be the zebu introgression into these two populations leading to homogenize both populations. When studying African taurine and zebu populations, Ibeagha-Awemu and Erhardt (2005) highlighted that neighboring domestic populations are usually poorly differentiated due to the existence of significant gene flow between them. Evidence supporting such a hypothesis were provided by the LDA. In fact, about $20 \%$ of both GourS and GourN individuals were reciprocally misclassified in 2018. This result may support the existence of possible ongoing gene flow between these populations. In fact, Sanguié, the sampling location of GourS individuals, is located in the Central part of Burkina Faso, characterized by low rainfall, a quite longer dry season, and poor pastures. In contrast, Nahouri (GourN cattle) is an area with luxury pastures and quite long rainy season. Sanguié farmers undertook migrations westward when the dry season approaches. As in several West African countries, Burkina Faso is characterized by a free grazing breeding system, unsupervised mating and lack of appropriate selection programs (Traoré et al., 2016, Moussa et al., 2019). Gene flow occurred due to these migrations could explain the Gourounsi population's homogenization.

However, barely $1.5 \%$ of the GourN was classified as GourS in the 2014 subset.
Interestingly, no noticeable changes in cattle management were observed between 2014 and 2018. Moreover, in 2014, Gourounsi populations (GourS and GourN) had higher mean values for Height at withers compared to Lobi. In 1987, when describing the Gourounsi taurine cattle, Planchenault (1987) termed them as "Mere" which is a general term used by Fulani (Peul) people to describe crossbreed between zebu and taurine cattle (similar to "sanga" cattle). Therefore, differences between Lobi cattle and Gourounsi cattle in 2014 can be linked to introgression of zebu cattle in all Gourounsi taurine cattle. The second hypothesis is then to be considered. Based on this observation, differences between GourS and GourN could be due to the different zebu admixture. Admixture analyses of African cattle using microsatellite data revealed a gradient of $B$. indicus introgression across the African continent (Hanotte et al., 2002), with the level of zebu introgression decreasing from eastern to western Africa (Hanotte et al., 2002: Freeman et al., 2006). Here, we give evidence based on body traits variation, which would be consistent with this introgression pattern. Smetko et al. (2015) explained this situation by the increasing presence of tsetse fly from East to West. Lobi cattle are in the South Sudan Savanna area that is the most humid area of the country. This zone is typical of the Sudanian tropical climate with bushy savannas and forest stands along its watercourses. These types of riverside vegetation are preferred biotopes of tsetse flies (Dayo et al., 2010). Given the susceptibility of most zebu cattle populations to trypanosomosis, Lobi distribution area is more challenging to zebu introgression and could explain the relative strong differentiation of this population between 2014 and 2018. Moreover, cultural reasons had to be associated. In Lobi country, pure Lobi cattle is demanded for wedding or dowry. Therefore, Lobi cattle are less likely to 
face severe introgression, as keeping the breed purity is a cultural concern. However, the ongoing climate change has reshaped the distribution of tsetse fly and then favorized introgression across years. Despite the existence of natural barriers, farmers sometime force the crossbreeding. Ouedraogo et al. (2020) when trying to implement a selection program in Lobi cattle area has come to identify that farmers prefer bigger, putatively more productive, and adapted for ploughing animals. MANOVA analysis gave clues for such increase in size.

\section{Conclusion}

Three shorthorn taurine cattle populations of Burkina Faso were assessed for body traits variation. A temporary pattern of variation was assessed; between and within populations variability for body traits significantly changed between 2014 and 2018 . In 2014 the two Gourounsi taurine populations (GourS and GourN) were clearly differentiated Moreover, a clear differentiation was assessed between Gourounsi and Lobi taurine cattle. In general terms, Lobi cattle were smaller than Gourounsi cattle populations. Within breeds, Gourounsi from Sanguié were bigger than Gourounsi of Nahouri. Differences within Gourounsi taurine cattle were probably due to differences in zebu admixture, with GourS being more admixed than GourN due to a lower of tsetse fly density in the Sanguie area. However, a strong homogenization signal has been identified within Gourounsi cattle population in 2018. Together with the increase in zebu admixture geneflow through migrations (transhumance) is likely to have led to this homogenization. Between breeds, Lobi cattle appeared less differentiated in 2018. The increased zebu introgression due to climate change and breeders' preferences seems to have diluted Lobi purebreeding. However, the existence of cultural reasons and the relative stronger pressure of trypanosomosis in the
Lobi breeding area have leaded to keep a higher proportion of pure cattle. The current research highlights the fast-genetic erosion of Burkina taurine cattle populations. This is consistent with all other African taurine populations. These cattle have a unique genetic assortment that deserved to be protected and fully explored. The lack of proper selection and conservation programs for these taurine cattle is a major issue that needs to be faced. Therefore, evidence shown in this study may be used to save Burkina Faso taurine cattle populations.

\section{COMPETING INTERESTS}

The authors declare no competing interest related to this manuscript.

\section{AUTHORS' CONTRIBUTIONS}

ASRT, AT and FG conceived the project; ASRT, BY, FGT, FB, DO, BLZ, and MS planned and performed the sampling. ASRT and AT performed most statistical analyses and drafted the manuscript; AS, VD, HHT, BB and FG revised the paper. All authors read, commented on and approved the final manuscript.

\section{REFERENCES}

Ajmone-Marsan P, Garcia, JF, Lenstra, JA. 2010. On the origin of cattle: how aurochs became cattle and colonized the world. Evolutionary Anthropology: Issues, News, and Reviews, 19(4): 148157. DOI: https://doi.org/10.1002/evan.20267

Álvarez I, Traoré A, Fernández I, Lecomte T, Soudré A, Kaboré A. Tamboura HH, Goyache F. 2014. Assessing introgression of Sahelian zebu genes into native Bos taurus breeds in Burkina Faso. Molecular Biology Reports, 41: 3745-3754. DOI: 10.1007/s11033-0143239-x

Álvarez I, Traoré A, Tamboura HH, Kaboré A, Royo LJ. Fernández I, Ouédraogo- 
Sanou G, Sawadogo L, Goyache F. 2009. Microsatellite analysis characterizes Burkina Faso as a genetic contact zone between Sahelian and Djallonké sheep. Animal Biotechnology, 20: 47-57. DOI: https://doi.org/10.1080/10495390902786 926

Blench RM, MacDonald KC. 2000. The origins and development of African livestock: archeology, genetics, linguistics and ethnography ( $1^{\text {st }}$ edn). Routledge: London. DOI: https://doi.org/10.4324/9780203984239

Boujenane I, Petit D. 2016. Between- and within-breed morphological variability in Moroccan sheep breeds. Animal Genetic Resources, 58: 91-100. DOI: https://doi.org/10.1017/S2078633616000 059

Dayo GK, Bengaly Z, Messad S, Bucheton B, Sidibe I, Cene B, Cuny G, Thevenon S. 2010. Prevalence and incidence of bovine trypanosomosis in an agropastoral area of southwestern Burkina Faso. Res. Vet. Sci., 88 : 470-477. DOI: http://dx.doi.org/10.1016/j.rvsc.2009.10. 010

FAO. 2011. Guidelines to Phenotypic characterization of Animal Genetic Resources. FAO, Rome, Italy.

Fagnon SM, Chikou A, Youssao I, Laleye P. 2013. Caractérisation morphologique des populations de Sarotherodon melanotheron (Pisces, Cichlidae) en eaux douces et saumâtres au Sud Bénin. Int. J. Biol. Chem. Sci., 7(2): 619-630. DOI:

http://dx.doi.org/10.4314/ijbcs.v7i2.18

Freeman A, Bradley DG, Nagda S, Gibson JP, Hanotte O. 2006. Combination of multiple microsatellite data sets to investigate genetic diversity and admixture of domestic cattle. Anim. Genet., 37:1-9. DOI: 10.1111/j.13652052.2005.01363.x
Hanotte O, Bradley DG, Ochieng JW, Verjee Y, Hill EW, Rege JE. 2002. African pastoralism: genetic imprints of origins and migrations. Science, 296: 336-339. DOI: $10.1126 /$ science. 1069878

Henn BM, Botigué LR, Gravel S, Wang W, Brisbin A, Byrnes JK, Fadhlaoui-Zid K, Zalloua PA, Moreno-Estrada A, Bertranpetit J, Bustamante CD, Comas D. 2012. Genomic Ancestry of North Africans Supports Back-to-Africa Migrations. PLoS Genet., 8(1): e1002397.

DOI: 10.1371/journal.pgen. 1002397

Ibeagha-Awemu E, Erhardt G. 2005. Genetic structure and differentiation of 12 African Bosindicus and Bostaurus cattle breeds, inferred from protein and microsatellite polymorphisms. J. Anim. Breed. Genet., 122:12-20. DOI: 10.1111/j.1439-0388.2004.00478.x.

Kassambara A. 2015. Factoextra: Extract and visualize the results of mulitivariate Data Analyses R package Version 1.0.3. Available at http//www.sthda.com

Lenth R. 2019. Emmeans: Estimated Marginal Means, aka Least-Squares Means. 2019 R Package Version 1.3.4. Available online : $\quad$ https://CRAN.Rproject.org/package=emmeans.

Charrad M, Ghazzali N, Boiteau V, Niknafs A. 2014. NbClust: An R Package for Determining the Relevant Number of Clusters in a Data Set. J. Stat. Soft, 61:136. DOI: $10.18637 /$ jss.v061.i06

Khan M, Rahim I, Rueff H, Jalali S, Saleem M, Maselli D, Muhammad S, Wiesmann U. 2013. Morphological characterization of the Azikheli buffalo in Pakistan. Animal Genetic Resources, 52: 65-70. DOI:

https://doi.org/10.1017/S2078633613000 027

MacDonald KC, Hutton MacDonald R. 2000. The origins and development of domesticated animals in arid West 
Africa. In The Origins and Development of African Livestock: Archaeology, Genetics, Linguistics and Ethnography, MacDonald KC (ed). UCL Press: London; 127-162. DOI: https://doi.org/10.1002/oa.576

MacHugh DE, Larson G, Orlando L. 2017. Taming the Past: Ancient DNA and the Study of Animal Domestication. Annual Review of Animal Biosciences, 5: 329351.

DOI:

https://doi.org/10.1146/annurev-animal022516-022747

Marshall F, Hildebrand E. 2002. Cattle before crops: the beginnings of Food production in Africa. Journal of World Prehistory, 16: 99-143. DOI: 10.1023/A:1019954903395

Moussa MMA, Gréma M, Tapsoba ARS, Issa M, Amadou T, Marichatou H, Pichler R, Soudré A, Sanou M, Tamboura HH, Yenikoye A, Periasamy K. 2019. Analyse de la diversité génétique de la race bovine Bororo (Wodaabé) du Niger à l'aide de marqueurs microsatellites. Int. J. Biol. Chem. Sci., 13(2): 1109-1126. DOI : http://ajol.info/index.php/ijbcs.

Ndumu BD, Baumung R, Hanotte $\mathrm{O}$, Wurzinger M, Okeyo MA, Jianlin H, Kibogo H, Solkner J. 2008. Genetic and morphological characterisation of the Ankole Longhorn cattle in the African Great Lakes region. Genet. Sel. Evol., 40: 467-490. DOI: 10.1186/1297-968640-5-467

Mwai O, Hanotte O, Kwon Y-J, Cho S. 2015. African Indigenous Cattle: Unique Genetic Resources in a Rapidly Changing World. Asian-Australas J. Anim. Sci., 28(7): 911-921. DOI: $10.5713 /$ ajas. $15.0002 \mathrm{R}$

Ouédraogo D, Soudré A, Ouédraogo-Koné S, Zoma BL, Yougbaré B, Khayatzadeh N, Burger PA, Mészáros G, Traoré A, Okeyo MA, Wurzinger M, Sölkner J. 2020. Breeding objectives and practices in three local cattle breed production systems in Burkina Faso with implication for the design of breeding programs. Livestock Science, 232: $103910 . \quad$ DOI: https://doi.org/10.1016/j.livsci.2019.103 910

Pérez-Pardal L, Sánchez-Gracia A, Álvarez I, Traoré A, Ferraz JBS, Fernández I, Costa V, Chen S, Tapio M, Cantet RJC, Patel A, Meadow RH, Marshall FB, BejaPereira A, Goyache F. 2018. Legacies of domestication, trade and herder mobility shape extant male zebu cattle diversity in South Asia and Africa. Sci. Rep., 8:18027. DOI: $10.1038 / \mathrm{s} 41598-018-$ 36444-7.

Pérez-Pardal L, Royo LJ, Beja-Pereira A, Curik I, Traoré A, Fernández I, Sölkner J, Alonso J, Álvarez I, Bozzi R, Chen S, Ponce de León FA, Goyache F. 2010. Yspecific microsatellites reveal an African subfamily in taurine (Bos taurus) cattle. Anim. Genet., 41: 232-241. DOI: 10.1111/j.1365-2052.2009.01988.x

Pindé S, Tapsoba ASR, Traoré FG, Ouédraogo RW, Ba S, Sanou M, Traoré A, Tamboura HH, Simporé J. 2020. Profils morpho-biometriques de la poule locale du Burkina Faso. Int. J. Biol. Chem. Sci., 14(6) : 2240-2256. DOI : https://dx.doi.org/10.4314/ijbcs.v14i6.25

Pitt D, Sevane N, Nicolazzi EL, MacHugh DE, Park SDE, Colli L, Martinez R, Bruford MW, Orozco-terWengel $P$. 2018. Domestication of cattle: two or three events? Evol. Appl., 12(1):123-136. DOI: 10.1111/eva.12674.

Planchenault D. 1987. L'Elevage : Elevage et Potentialités Pastorales Sahéliennes, Synthèses Cartographiques au Burkina Faso. CIRAD-IEMVT

FRA.Wageningen: Wageningen.

Smetko A, Soudre A, Silbermayr K, Müller S, Brem G, Hanotte O, Boettcher PJ, Stella A, Mészáros G, Wurzinger M, Curik I, 
Müller M, Burgstaller J, Sölkner J. 2015. Trypanosomosis: potential driver of selection in African cattle. Front. Genet., 6:137. DOI: $10.3389 /$ fgene.2015.00137

Traoré A, Álvarez I, Fernández I, PérezPardal L, Kaboré A, Ouédraogo-Sanou GMS, Zaré Y, Tamboura HH, Goyache F. 2012. Ascertaining gene flow patterns in live- stock populations of developing countries: a case study in Burkina Faso goat. BMC Genetics, 13: 35. DOI:10.1186/ 1471-2156-13-35

Traoré A, Álvarez I, Tamboura $\mathrm{HH}$, Fernández I, Kaboré A, Royo LJ, Gutiérrez JP, Ouédraogo-Sanou G, Sawadogo L, Goyache F. 2009. Genetic characterisation of Burkina Faso goats using microsatellite polymorphism. Livestock Science, 123: 322-328. DOI: 10.1016/j.livsci.2008.11.005

Traoré A, Koudandé DO, Fernandez I, Soudré A, Granda V, Alvarez I, Diarra S, Diarra F, Kaboré A, Sanou M, Tamboura HH, Goyache F. 2015. Geographical assessment of body measurements and qualitative traits in West African cattle. Trop. Anim. Health Prod., 47: 15051513.

DOI:

https://doi.org/10.1007/s11250-0150891-7

Traoré A, Koudandé DO, Fernández I, Soudré A, Álvarez I, Diarra S, Diarra F, Kaboré A, Sanou M, Tamboura HH, Goyache F. 2016. Multivariate characterization of morphological traits in West African cattle sires Arch. Anim. Breed., 59: 337344. DOI: 10.5194/aab-59-337-2016

Yahaya ZI, Dayo GK, Maman M, Issa M, Marichatou H. 2019. Caractérisation morphobiométrique du zébu Djelli du Niger. Int. J. Biol. Chem. Sci., 13(2): 727-744. DOI : 10.4314/ijbcs.v13i2.13

Youssao I, Tobada P, Koutinhouin B, Dahouda $\mathrm{M}$, Idrissou $\mathrm{N}$, Bonou $\mathrm{G}$, Tougan U, Ahounou S, Yapi-Gnaoré CV, Kayang B. 2010. Phenotypic characterisation and molecular polymorphism of indigenous poultry populations of the species Gallus gallus of Savannah and Forest ecotypes of Benin. African Journal of Biotechnology, 9(3): $\quad 369-381 . \quad$ DOI : https://doi.org/10.5897/AJB09.1220.

Wendorf F, Schild R. 2005. Are the early Holocene cattle in the eastern Sahara domestic or wild? Evol. Anthropcol., 3:118-128.

DOI: https://doi.org/10.1002/evan.136003040 6

Zerabruk M, Li M-H, Kantanen J, Olsaker I, Ibeagha-Awemu EM, Erhardt G, Vangen O. 2012. Genetic diversity and admixture of indigenous cattle from North Ethiopia: implications of historical introgressions in the gateway region to Africa. Anim. Genet. $\quad 43$ : 257-266. DOI: 10.1111/j.1365-2052.2011.02245.x 